\title{
6章 視覚・言語のデータセット
}

\section{吉川友也}

キーワード：画像・動画の説明文生成, キャプション生成, ビジュアル質問応答, データセット

\section{1. まえがき}

これまでの章では, 画像・動画と言語を融合した研究課 題とそれらを解決するための手法が主に紹介されてきた. これらの手法の出力結果は, その手法を学習するために用 いたデータセットによって異なるため, 用途に合わせて データセットを変える必要がある。また，用途に合うデー タセットが存在しなければ, データセットの構築も検討す るべきだろう。したがって，さまざまなデータセットを 知って打くことは, 所望の出力を得るためには重要である.

本稿では, 画像・動画と言語を融合した研究課題の一例 として, 画像・動画の説明文生成と画像に対する質問応答 を取り上げ，これらの研究において最近構築されたデータ セットを比較するとともに, どのように構築され, どのよ うなアノテーションが付与されているのかを概説する. ページ数制約のため, 各データセットの詳細については元 論文を参照されたい.

\section{2. 画像の説明文データセット}

画像から説明文 (またはキャプション)を生成するモデル は，教師あり学習により訓練される。ささまざまなシーンや 物体を認識し, それを充分な語彙で説明するためには, 画 像と説明文のペアが大量に必要となる.

最近の主要なデータセットの特徵を表 1 にまとめた。画 像の説明文生成のベンチマークとして標準的に用いられて いるのはMS-COCOやFlickr8k/30kである.これらは画像 に対して単文の説明文が付けられている. 画像中のさまざ まな箇所に説明文を付与したデータセットとしてはVisual Genomeが有名である.また, Visual Genomeの画像に対し て1パラグラフの説明文を付与したデータセットもある16).

最近の画像の説明文データセットの多くは，(1)説明文を 付与する画像を収集, (2)クラウドソーシングで説明文を付

$\dagger$ 千葉工業大学 人工知能・ソフトウェア技術研究センター

"Datasets for Vision and Language Research" by Yuya Yoshikawa, Yutaro Shigeto and Akikazu Takeuchi (STAIR Lab, Chiba Institute of Technology, Chiba)
表 1 画像の説明文データセットの一覧

\begin{tabular}{|c|c|c|c|c|}
\hline データセット & 説明対象 & 単位 & 画像数 & 平均説明数 \\
\hline Pascal Sentence ${ }^{22)}$ & 画像全体 & 文 & 1,000 & "5 \\
\hline MS-COCO ${ }^{3)}$ & 画像全体 & 文 & 123,287 & 5 \\
\hline Flickr8k ${ }^{8)}$ & 画像全体 & 文 & 8,092 & 5 \\
\hline Flickr30k ${ }^{32)}$ & 画像全体 & 文 & 31,783 & 5 \\
\hline Visual Genome $^{18)}$ & 部分領域 & 文 & 108,077 & 50 \\
\hline Krause et al. ${ }^{16)}$ & 画像全体 & 段落 & 19,551 & 1 \\
\hline
\end{tabular}

与, (3)付与された説明文の選別や修正, の各ステップに よって構築されている.

それぞれのステップにおいて，データセット毎に異なる 特徵が見られる。画像に関しては, Flickrから収集した画 像がよく利用される。ただし，画像の著作権に関してはさ まざまな物が混在しているため, 使用に関しては注意が必 要となる. Flickr 以外の画像を用いたケースとして, Abstract Scenes Dataset ${ }^{36)}$ では，クリップアートを合成し て作成した画像を用いている.

クラウドソーシングによる説明文付与に関しては，英語 のデータセットが多いということもあり, Amazon Mechanical Turk (AMT) がよく利用されている。日本語 説明文を付与したケースでは, YJ Captions ${ }^{20)}$ はYahoo!ク ラウドソーシング, STAIR Captions ${ }^{31)}$ はクラウドワーク スとCROWDが用いられている. 説明文付与の際, ワー カーにはガイドラインが示される。例えば，MSCOCOで は, 説明文は, (1) 8 単語以上, (2) 重要なシーンの説明だけ, (3) 過去や未来について書かない, (4)人の固有名詞は書か ない，等が指示されている．また，日本語特有のガイドラ インとしては, STAIR Captionsは「だ・である」調で説明 文を書くように指示している.

上記ステップで付与された説明文には，スペル誤りや文法 的誤り，ガイドライン違反等が見られる。 このような説明文 を除去または修正するために，新たにクラウドソーシングを 行い，スペル誤りや文法的誤りがある場合は修正をしたり， ガイドラインに沿っているかどうかの判定を行い，沿ってい 
ないものを除去したりする作業が行われている。この作業は 最終的なデータセットの品質に関わるものであるが，データ セット毎に対応が異なるため注意が必要である.

\section{3. 動画の説明文データセット}

動画の説明文生成は, 基本的には画像の説明文生成の入 力が画像から動画に変わったものとなる.したがって, データセットの作成方法も画像の説明文と同様のステップ で行われる。

表2には最近の主要な動画の説明文データセットとそれ らの統計量をまとめた．動画の説明文生成において標準的 と言えるデータセットはまだないが，MSR-VTT, ActivityNet Captions, LSMDCは国際会議で行われたコン ペティションで使用された実績がある.

説明文を付与する対象の動画は, データセット毎にさま ざまなリソースから収集されている. YouCook, MSRVTT, ActivityNet Captionsは, YouTubeから収集された 動画が利用されている. 特に, YouCook は料理動画だけを 集め，MSR-VTTはシーンが偏らないようにさまざまなク エリで動画を検索して収集している，LSMDCは，DVDや Blu-rayの映画から動画を収集している。このデータセッ トでは, 映画の脚本や音声解説の書き起こし文も利用可能 である、上記のように既存の動画を集めるのではなく, 新 たに撮影した動画を利用するケースもあるＴACoS multilevelの動画は, ワーカーに料理の手順を示してその指示通 りに料理をしてもらった動画である。また，Charadesは キーワードからの台本作成を $\mathrm{AMT}$ で行い, その台本に基 づいてAMTで動画撮影を依頼し著作権フリーの動画を収 集している.

動画に対する説明文付与は, 画像の説明文と同様にクラ ウドソーシングで行われる. MSR-VTTは動画を数十秒の 短い動画にして，それらに対して単文の説明文付与を行っ ている。このような処理を行わず, 動画全体に説明文を付 与するケースでは, TACoS Multi-levelは, 動画1本に対し
表2 動画の説明文データセットの一覧

TACoS M-LはTACoS multi-levelの略. AN Captionsは ActivityNet Captionsの略.

\begin{tabular}{|c|c|c|c|c|}
\hline データセット & 動画数 & クリップ数 & 合計説明文 & 平均クリップ長 \\
\hline MSVD ${ }^{2)}$ & - & 1,970 & 70,028 & 10秒 \\
\hline YouCook $^{5)}$ & 88 & - & 2,668 & - \\
\hline TACoSML 25$)$ & 127 & 14,105 & 52,593 & 360 秒 \\
\hline Charades $^{26)}$ & 10,000 & 10,000 & 16,129 & 30 秒 \\
\hline MSR-VTT ${ }^{30)}$ & 7,180 & 10,000 & 200,000 & 20 秒 \\
\hline LSMDC $^{24)}$ & 202 & 118,081 & 118,081 & 4.8 秒 \\
\hline ANCaptions $^{17)}$ & 19,994 & 100,000 & 100,000 & 180 秒 \\
\hline
\end{tabular}

て詳細に記述した複数の説明文, 短く記述した複数の説明 文，動画全体を表す 1 つの説明文の 3 種類が付与されてい る. ActivityNet Captionsでは, 動画1本を説明する1パラ グラフ分の説明文をワーカーに付与してもらい, その後, そのパラグラフの各文が動画中のどの時間区間に対応する かを付与してもらうことで, 時間区間の重複を含む説明文 が付けられている。

\section{4. 画像を対象とした質問応答データセット}

キャプション生成と同様に, 画像・動画を対象とした質 問応答に関する研究も盛り上がりを見せている。 それに伴 い，新たなデータセットが次々に構築されている，本節で は，主に画像を対象とした質問応答データセットの紹介を 行う.

表3に，代表的な画像を対象とした質問応答データセッ トを示す．各データセットは，画像に対して質問とその応 答が付与されている，質問応答を付与する画像には，実画 像を用いる場合と人工画像を用いる場合の 2 通りの方法が ある。実画像を用いたデータセットに注目した場合， DAQUARを除いたすべてのデータセットにおいて実画像 としてMS-COCOを用いている.

FM-IQA ${ }^{6)}$ とVisual7W ${ }^{35)} に は$, 他のデータセットにはな

表3 質問応答データセットの比較

アノテーション列における，Aは質問応答を自動で作成，Mは人手で作成したデータセットであることを示している，タスク列に おける，MCは応答を候補から選択する (Multiple Choice) タスクであり，OEは応答を生成する (Open-Ended) タスクである.

\begin{tabular}{|c|c|c|c|c|c|}
\hline データセット & 画像数 & 質問応答数 & アノテーション & 画像 & タスク \\
\hline DAQUAR ${ }^{19)}$ & 1,449 & 12,468 & $\bar{A} \cdot \mathrm{M}$ & NYU Depth Dataset V2 & 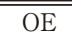 \\
\hline FM-IQA6) & 316,193 & 158,392 & $\mathrm{M}$ & MS-COCO & $\mathrm{OE}$ \\
\hline COCO-QA23) & 123,287 & 117,684 & $\mathrm{~A}$ & MS-COCO & $\mathrm{OE}$ \\
\hline Visual7W35) & 47,300 & 327,939 & M & MS-COCO & $\mathrm{MC}$ \\
\hline Visual Genome ${ }^{18)}$ & 108,077 & $1,773,258$ & $\mathrm{M}$ & MS-COCO,YFCC100M & $\mathrm{MC}$ \\
\hline VQA (abstract) ${ }^{1)}$ & 50,000 & 150,000 & $\mathrm{M}$ & 人工画像 (クリップアート) & $\mathrm{OE}$ \\
\hline VQA (balanced-abstract) 7) & 31,325 & 33,383 & $\mathrm{M}$ & 人工画像 (クリップアート) & $\mathrm{OE}$ \\
\hline VQA (balanced-real) ${ }^{34)}$ & 204,721 & $1,105,904$ & $\mathrm{M}$ & MS-COCO & $\mathrm{OE}$ \\
\hline CLEVR10) & 100,000 & 864,968 & $\mathrm{~A}$ & 人工画像 (3D レンダリング) & $\mathrm{OE}$ \\
\hline TDIUC ${ }^{11)}$ & 167,437 & $1,654,167$ & $\mathrm{~A} \cdot \mathrm{M}$ & MS-COCO & $\mathrm{OE}$ \\
\hline
\end{tabular}


い特色があるＦM-IQA は，質問応答が英語だけではなく 中国語でも付与されている*1.Visual7W は，「Which pillow is farther from the window?」のような物体を特定 する質問に対しては，言語による応答に加えて，画像中の 対応する物体にバウンディングボックスも付与してある.

$\mathrm{VQA}^{1)}$ は，頻繁にベンチマークとして利用されている. VQA は, real imagesデータセットと abstract scenesデー タセットの 2 種類のデータセットから構成されている. Real imagesデータセットは，MS-COCOに含まれる写真を 基にしたデータセットであり， abstract scenesデータセッ トは，クリップアートを使って人工的に生成した画像で構 成されている。これらのデータセットは，AMTを使い人 手で質問と応答が付与されている*2. 作業者には「人間に は簡単に答えられるが，ロボットには答えられない質問」 を付与するように指示されており，「What is ...」，「Is there ...」, 「How many ...」, 「Does the ...」などのフレーズ で始まる質問がデータセットに存在する.

現在公開されている最新のVQA は第2 版 (balanced VQA データセット) 34) 7) となっている. 第2版は, 第 1 版 に存在したデータセットに存在するバイアスを除去するよ うにデータセットの改善を行っている.このバイアスとは, データセットに存在する応答の偏りのことを意味してい る. 例えば，第1版において「What sport is ...?」から始ま る質問に対する正しい応答の $41 \%$ が「tennis」である。また $\lceil$ How many ...?」に対する正しい応答の39\%が「2」となって いる。 その結果として，質問応答システムが害際に画像を 理解せずとも，偏った回答を記憶(例えば「What spor ...?」 に対して常に「tennis」と回答) することにより高い性能に 達して（いるように見えて）しまう。このようなシステムは 本質的に役に立たず，実応用上でも好ましくない，VQA 第2版では，原因となるバイアスを除去しており，質問に 正しく応答するためには画像の理解が必要である, と主張 している.同様にバイアスが抑えられたデータセットとし てCLEVR ${ }^{10)}$ と TDIUC ${ }^{11)}$ が構築されている.

表には記していないが，特色がある質問応答データセッ 卜を簡単に紹介する，図中に含まれるダイアグラムの理解 を目的とした $\mathrm{AI} 2 \mathrm{D}^{13)}$ ，教科書に記載された文章と図の理 解を目的とした $\mathrm{TQA}{ }^{14)}$ ，棒グラフや折れ線グラフなどの グラフを質問の対象としたFigureQA ${ }^{12)}$, 常識や外部知識 に注目した KB-VQA ${ }^{29)} ， \mathrm{FBQA}^{28)}$ ，質問と応答を対話とし て付与した $\mathrm{VisDia}^{4)}$ ，質問応答を文の穴埋め問題として取 り扱っているVisual Madlibs ${ }^{33}$ がある.

画像に対する質問応答に注目して説明を行ったが，動画 に対する質問応答も盛んに研究されている.データセット

*1 正確には, はじめに中国語で質問応答を付与し, その後, 中国語を 英語に翻訳している。

*2 Abstract scenesデータセットに対しては, 各画像に対して5個の キャプションも付与されている.

$674 \quad(32)$
としてMovieQA27), MarioQA21), TGIF-QA ${ }^{9)}$, PororoQA ${ }^{15)}$ が構築されている．動画に対する質問応答で は，画像では扱えない事象に注目し，質問が付与されてい る。例えば，TGIF-QA データセットには「How many times does the man wrap string?」, 「How many times does the cat touch the dog?」や「What does the bear on right do after sitting?」などの画像からでは応答できない ような質問が含まれている.

\section{5. むすび}

本稿では，画像・動画の説明文生成と画像を対象とした 質問応答に打ける最近のデータセットについて紹介した。 最近のデータセットは，クラウドソーシングを駆使してア ノテーションすることにより，非常に大規模になっている. このような大規模なデータセットが存在するからこそ， ニューラルネットワークのような大量のパラメータを持つ 複雑なモデルを学習可能にしていると言えるだろう。参考 文献に目を通していただくとわかるが，毎年新たなデー夕 セットが公開されている. 媣層学習の発展, クラウドソー シングプラットフォームの整備などもあり，今後も新たな データセットが構築され続けると思われる。実際に今年 （2018年）のCVPRに抏いても，新しいデータセットが発表 されるようである*3. そのため，ベンチマークの定番であ る MS-COCOやVQA データセットが今後も定番であり続 けるとは限らず，新たに構築されるデータセットの情報を 継続して調査する必要がある.

謝辞 この成果は，国立研究開発法人新エネルギー・産 業技術総合開発機構 (NEDO)の委託業務の結果得られたも のです.

(2018年5月 31 日受付)

\section{〔文 献〕}

1) A. Agrawal, et al.: "VQA: Visual Question Answering", In ICCV (2015)

2) D.L. Chen, et al.: "Collecting Highly Parallel Data for Para phrase Evaluation", In ACL (2011)

3) X. Chen, et al.: "Microsoft COCO Captions: Data Collection and Evaluation Server", In ECCV (2015)

4) A. Das, et al.: "Visual Dialog", In CVPR (2017)

5) P. Das, et al.: "A Thousand Frames in Just a Few Words: Lingual Description of Videos through Latent Topics and Sparse Object Stitching", In CVPR (2013)

6) H. Gao, et al:: "Are You Talking to a Machine? Dataset and Methods for Multilingual Image Question Answering". In NIPS (2015)

7) Y. Goyal, et al.: "Making the V in VQA matter: Elevating the role of image understanding in visual question answering", In CVPR (2017)

8) M. Hodosh, et al.: "Framing Image Description as a Ranking Task Data, Models and Evaluation Metrics", JAIR (2013)

9) Y. Jang, et al.: "TGIF-QA: Toward Spatio-Temporal Reasoning in Visual Question Answering", In CVPR (2017)

10) J. Johnson, et al.: "CLEVR: A Diagnostic Dataset for Compositional Language and Elementary Visual Reasoning", In CVPR (2017)

*3 執筆段階に打いて, CVPR 2018の会議録が公開されていないため, 今回は説明する対象から除外した。 
